\title{
MIRŐL ÁRULKODNAK A CSEPPKÖVEK? - A BARLANGOK VILÁGA
}

What about are the dripstones telling? - The world of the caves

\section{LEÉL-ŐSSY SZABOLCS}

ELTE TTK Földrajz- és Földtudományi Intézet Általános és Alkalmazott Földtani Tanszék

leel-ossy.szabolcs@ttk.elte.hu

\section{ABSTRACT}

Human is descended from cave-dwelling ancestors; therefore the dark caves have struck the people with awe. In the nature there are several types of the caves, of which genesis is connected mostly to the limestones and to the dissolving effect of the water; however, there are other natural caverns originating syngenetic with the rocks. The principally known formations of the caves are the dripstones, which are slowly forming, vulnerable natural values. Nevertheless, they have also other significance, because due to up-to-date investigation methods of materials testing new knowledge can be achieved concerning their genesis and age, moreover about the climatic conditions which were dominant during their origin.

Keywords: cave research, cave types, evolution of dripstones, isotope analysis, climate change, palaeoclimatic investigation

\section{A BARLANGOK KELETKEZÉSE ÉS TÍPUSAI}

A barlangok föld alatti, zárt világa egyszerre vonzó és titokzatos az emberek számára. Pedig emberré válásunk egyik legfontosabb tényezője, helyszíne volt a barlang, őseink itt találtak menedéket a vadállatok és a hideg elől. Nem véletlen, hogy a történelem előtti régészeti lelöhelyeink nagy része különböző barlangokhoz kötődik (pl. a Bükkben a Szeleta-barlanghoz, a Suba-lyukhoz, a Kecske-lyukhoz). Magyarországon mintegy 4000 barlangot tartanak nyilván (http://www.termeszetvedelem.hu/index.php?pg=caves), ebböl jelenleg 104 régészetileg is jelentős. A barlangoknak csak egy része nyitott természetes módon, többségük csak valamilyen emberi beavatkozás (pl. kőbányászat, kútásás, házalapozás, vezetékfektetés), vagy kitartó feltáró kutatás (pl. a befolyó patak vizének megfestése vagy az eltömődött víznyelö kőtörmelékének kitermelése) nyomán vált ismertté. A budapesti meleg vizes barlangokban a belső részek eltömődéseit évtizedek óta kutatják, bontják. A leghosszabbat, a Pál-völgyi-barlangrendszert pl. sok tucat lépésben tárták fel több mint egy évszázad alatt! Jellemző adat, hogy Budapesten a 19. század végén csak néhány tíz méter barlangjárat volt ismert, ma viszont már több mint 55 km (LEÉL-Őssy Sz. - VIRÁg M. 2018). 
A barlangok nagy része a karbonátos kőzetekből, főleg a mészkőből álló hegységekhez, illetve azokban a föld alatti vízfolyásokhoz kapcsolódik. A fentebb említett, az ősember által használt barlangok többnyire forrásbarlangok, amelyek rendszerint több méter átmérőjü szádával (bejárattal) rendelkeznek (1. ábra). Itt általában kőzettani vagy tektonikai okokból (pl. egy repedés, hasadék mentén, vagy egy kissé vízzáró réteget, közbetelepülést elérve) lép felszínre a föld alatt hosszabb-rövidebb utat bejárt szivárgó, csordogáló, folyó víz. Ha később a terület kiemelkedett, vagy a felszíni vizek bevágódása folytán az erózióbázis, és így a karsztvíz szintje a kőzetben alacsonyabb szintre helyeződött át, akkor a régi forrásbarlangok gyakorta teljesen szárazzá váltak, és ma a völgytalpak fölött különböző magasságokban helyezkednek el (JAKUCs L. 1971). Ezek kínáltak kiváló megtelepedési lehetőséget az ősembernek.

A föld alatti vízfolyások kiinduló pontjai a víznyelők. Ezek elhelyezkedhetnek a karszt belsejében (pl. a Bükk esetében ilyenek pl. a Bolhási-, a Jávorkúti- és a Pénzpataki-víznyelők); hozzájuk általában rövid és időszakos patakmedrek vezetik a vizet, amelyek az év nagy részében szárazak, csak hóolvadás vagy nagyobb esőzések idején aktívak. Általában bővebb vizüek az ún. karsztszéli víznyelők; esetükben a vízzáró kőzeten alakul ki a patak, ami nekifut egy - a térszínből kiemelkedő - karsztos kőzetanyagú hegynek; ilyenek pl. az Aggtelek és Jósvafő közötti víznyelők, amelyek a Baradlát táplálják (JAKUCs L. 2005).

Ritkaság azonban, hogy egy barlangon a víznyelőtől a forrásig végig lehessen sétálni: még Szlovéniában, a Karszt-hegység bő vizü föld alatti vízfolyásai esetében is elválnak

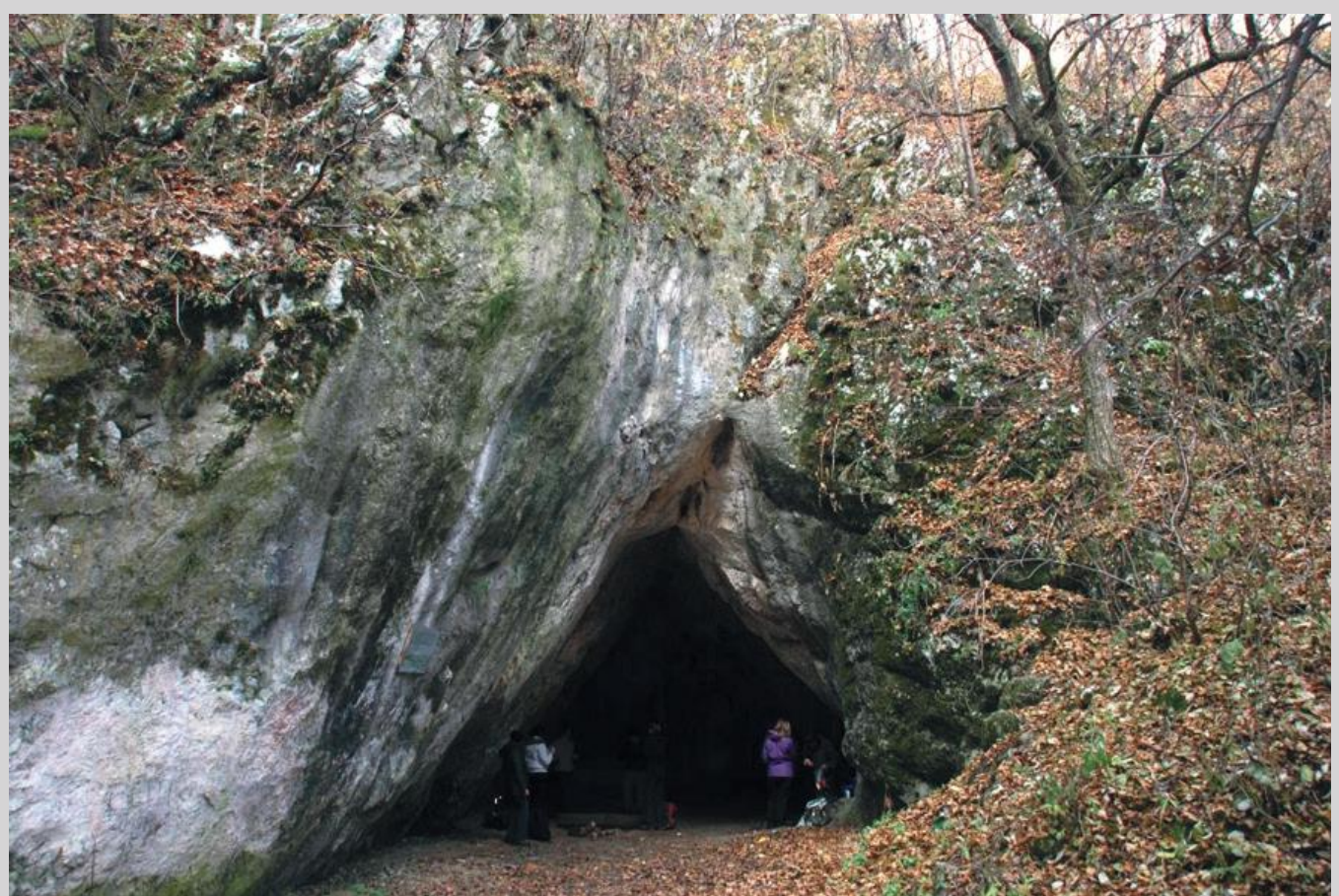


egymástól a víznyelőbarlangok és a forrásbarlangok. A világhírű szlovéniai Postojnaibarlangba befolyó Pivka folyó sem követhető végig a föld alatt; bár tudjuk, hogy később az Otoska-, majd a Fekete- és Pivka-barlangokban ismét előjön a vize, de közben több helyen a folyó a mennyezetig kitölti a barlangot (az ilyen szakaszok a barlangi szifonok, amelyek átjárhatatlanok).

Hazánkban a Gömör-Tornai-karszton a Baradla és Béke-barlang is csak majdnem átmenő barlang: a kijárati szakaszt mindkét barlangban mesterségesen alakították ki robbantás segítségével. A Mecsek Abaligeti-barlangjának esetében a második nyugati mellékág mellékágába vezető Akácos-víznyelőn keresztül (nagy nehézségek árán) eljuthatunk a barlang fó ágába, és azon keresztül a forrásnál a felszínre, de itt sem mehetünk végig a fö víznyelőtől a forrásig. A Bükkben az utóbbi években feltárt SzivárványSebes-víz-barlangrendszer számít átmenő barlangnak, de itt a bejutás nem a fö víznyelö, hanem a bevezető szakasz egyik felszakadása mentén történik. Ezeknek a patakos barlangoknak a létrejöttét is a kőzet szerkezeti repedései teszik egyáltalán lehetővé (Ford, D. - Williams, P. 2007).

A hideg vizes eredetü, „normál karsztos” barlangoktól eltérő módon keletkeztek a hipogén barlangok, amiket szoktak termálkarsztos, vagy egyszerüen hévizes barlangoknak nevezni. Nincs bennük vízfolyás, hanem föleg az alulról feltörő, különböző hőmérsékletű és ionos összetételű forrásvizek elegyedése során fellépő ún. keveredési korrózió oldásának köszönhetik kialakulásukat (GuNN, J. 2004). A forrásvizek a mélyből a kőzetek tektonikai repedésein keresztül emelkednek a felszínre. Ezek általában nem juvenilis vizek, amelyek még nem jártak a Föld felszínén, hanem régebbi csapadékvizek, amik kicsit távolabb, a beszivárgási területen jutottak be a karsztba, és néhány száz, néhány ezer, vagy néhány tízezer évet töltöttek el a hegység belsejében, és esetlegesen 1-2 km mélységbe is eljutottak. Ilyen vízkörzés (2. ábra) alakult ki pl. a Budai-hegységben, és hozta létre félmillió-egymillió évvel ezelőtt azt a ma kb. $55 \mathrm{~km}$ összhosszúságban ismert barlangvilágot a Rózsadomb városrész környékén, aminek a Pál-völgyi-barlang és a Szemlö-hegyibarlang (részben idegenforgalmilag kiépített járatokkal) a leghíresebb képviselői. Persze hazánkban máshol (pl. a Villányi-hegységben) is vannak hasonló keletkezésű barlangok.

A mészkő oldásának fö hatótényezője általában a szén-dioxid (ill. a szénsav), de a Földön vannak olyan területek, ahol ezt a szerepet a kénsav játszotta (pl. az USA-ban, Új-Mexikóban a Guadalupe-hegységben). Újabban egyes hazai barlangok (pl. a Sátorköpusztai-barlang) kialakulásának esetében is felvetik a kénsav esetleges szerepét.

A nagyobb barlangok általában a fentebb leírt típusok képviselői. Mindannyian utólagosan, a karsztosodás folyamatával, a víz oldó hatása segítségével kialakult ún. epigenetikus barlangok. Létrejöttükben a tektonikus eredetű repedéseknek-hasadékoknak nagy szerepük volt. Szerényebb méretü epigenetikus (posztgenetikus) barlangok 


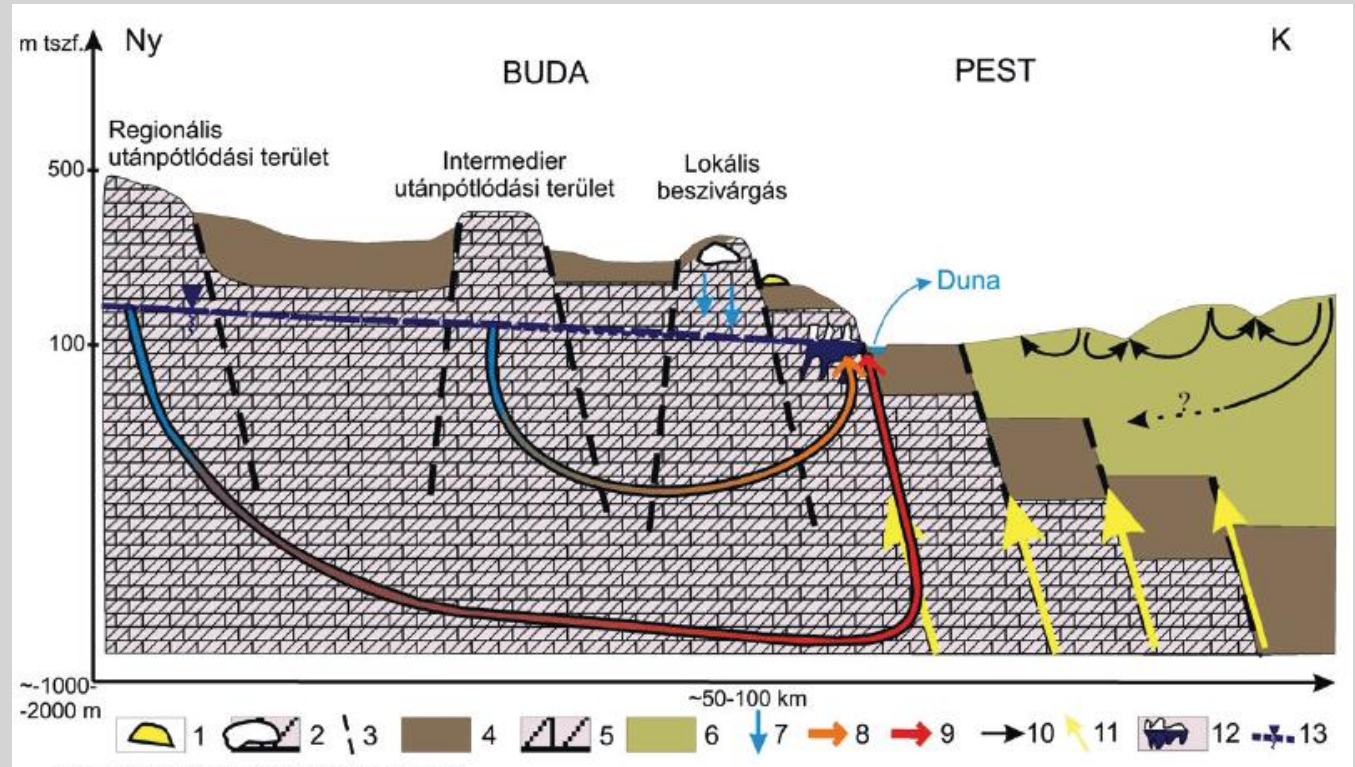

A Budai Termálkarszt áramlási rendszerei:

Jelkulcs: 1: travertinó; 2: inaktiv, száraz barlang; 3 : vetö; 4: oligocén agyagok; 5 : karbonátok; 6 : neogén üledékek; 7: lokális

beszivárgás; 8 : meteorikus karsztviz áramlás; 9 : regionális karsztviz komponens; 10: gravitációsan vezérelt áramlási rendszerek

a pesti oldalon; 11: tektonikus kompresszió által vezérelt medencefluidumok; 12: hipogén aktív barlang; 13: karsztviztükör

\section{2. ábra. A Rózsadomb környékének elvi vízkörzése (ERőss A. et al. 2010 nyomán)}

kialakulhatnak pusztán szerkezeti mozgások során, vagy felszíni folyóvizek, illetve a tengerparti hullámzás (ez utóbbiak általában csak beöblösödések), esetleg a szélmarás eróziós-korróziós munkája során is (3. ábra). Ezeknél a barlangoknál a kőzet keletkezése és az üreg létrejötte (szinte minden esetben a kissé savas víz oldó hatása következtében, esetleg az eróziós tevékenység rásegítésével) időben elválik. A legtöbb barlang a sokszor több száz millió éves kőzetekhez képest nagyon fiatal, „mindössze” néhány százezer, esetleg néhány millió éves.

Más a helyzet a kőzettel egy időben kialakuló szingenetikus barlangokkal. Az édesvízi mészkőben (travertínó, vagy forrásvízi mészkő, elterjedt - de vitatható - elnevezéssel mésztufa) kialakult szintén kisebb térfogatú, izolált üregeket létrejöttükkor zárta közre a lassan leülepedő kőzet (VEress M. 2004; 4. ábra). Ilyen kis üregeket kötöttek össze a lillafüredi Anna-barlang kiépítésekor hosszabb-rövidebb mesterséges tárókkal.

Persze nemcsak karbonátos kőzetekben alakulhatnak ki a kőzet keletkezésével egyidőben barlangok, hanem pl. magmás vagy vulkanikus kőzetben is. Ezek közül a legnagyobb méretűek a lávacsőbarlangok, amelyek lávafolyásokban alakultak ki. 


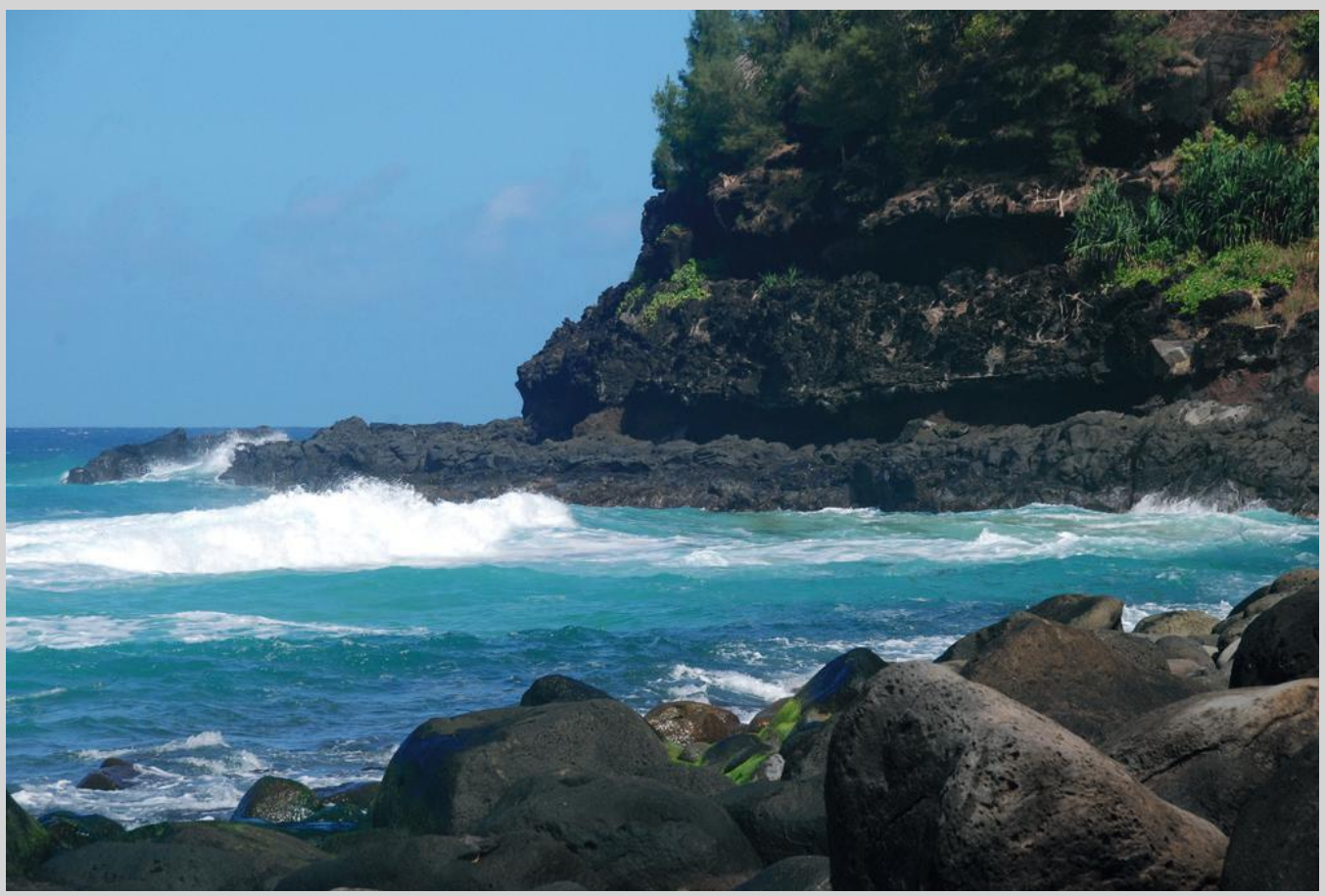

3. ábra. Hullámzás létrehozta abráziós barlangfülkék sora a Hawaii-szigetek Kauai szigetén (fotó: Leél-Össy Sz.)

Különösen a hígan folyó bazaltos lávára jellemzők. Amikor a vulkán lávaszolgáltatása befejeződik, a lávafolyás felszíne hamar megdermed, de néhány méterrel mélyebben még folyékony az izzó kőzetolvadék, ami kifolyik a megdermedt lávafelszín alól, így hosszan kígyózó, a metró alagútjához hasonló barlangok alakulhatnak ki (5. ábra). Izlandon, Szicíliában, a Kanári-szigeteken vagy Dél-Koreában a Jeju-szigeten gyakoriak, de a legnagyobbak a Hawaii-szigetek legnagyobbikán, a névadó Hawaii-szigeten (Big Island) találhatók: a Kazumura-barlang hossza $65,5 \mathrm{~km}$, az általa áthidalt szintkülönbség pedig meghaladja az 1100 métert (GeoMetodika 2020.11.30.). Hazánkban is sok tucat vulkanikus barlang van, de azok nem lávacsőbarlangok, és a hosszuk is sokkal szerényebb, általában néhány méteresek, esetleg néhány tíz méteresek. Mélységi magmás kőzetekben a megszilárduláskor létrejöhetnek izolált üregek („kristálypincék"). Oldalfalukon találjuk a legszebb, síklapokkal határolt ásványokat, az ún. fennőtt kristályokat (ezeket nevezték régen bányavirágoknak).

Az összes eddig említett barlang esetében az a közös, hogy valamennyi természetes eredetű, és a Föld szilárd kérgében alakult ki. Ezt emeli ki a természet védelméről szóló, 


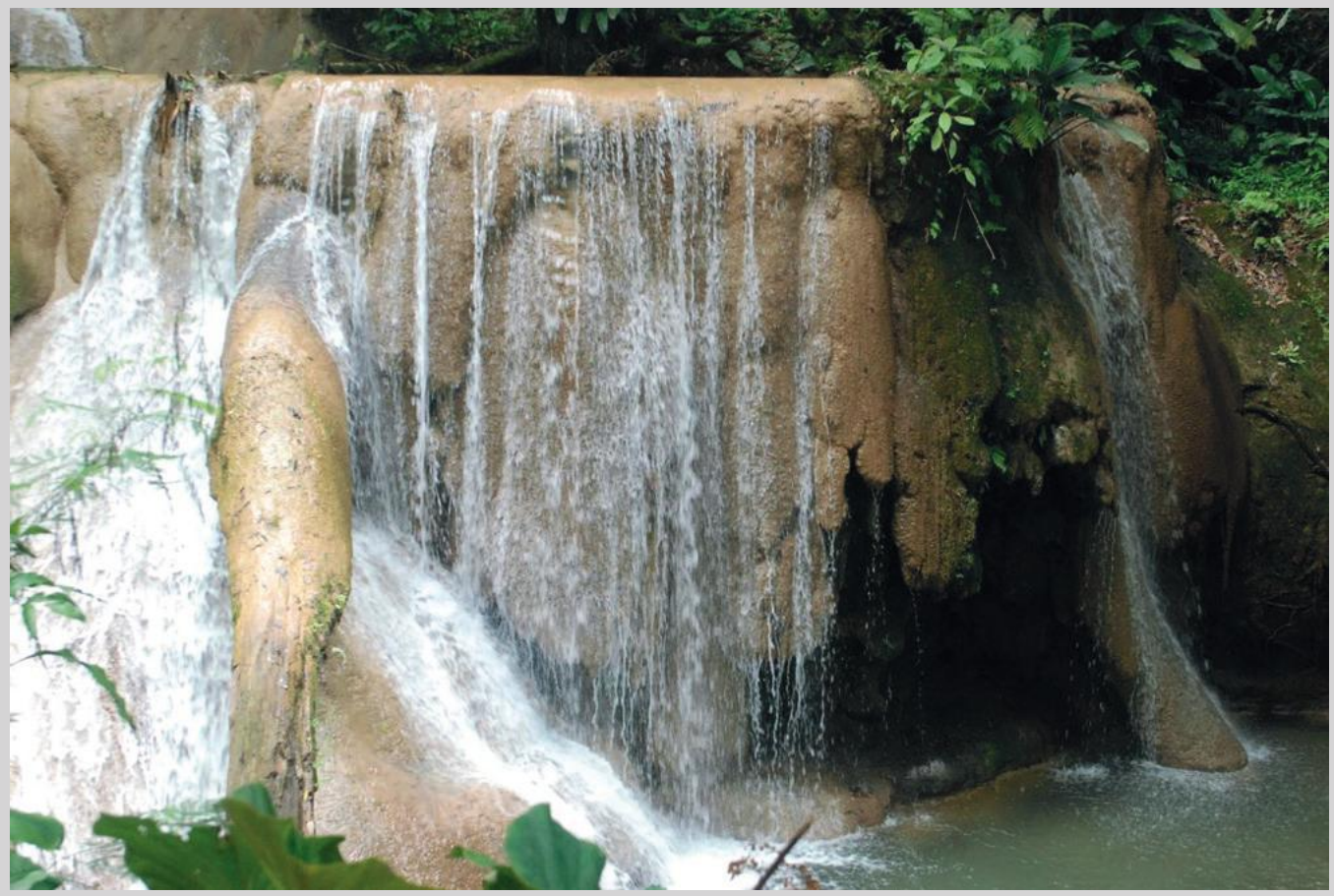

4. ábra. Keletkezö barlangüreg édesvizi mészkőben a mexikói Aqua Azul-vizesésnél (fotó: Leél-Őssy Sz.)

5. ábra. A Meglepetés (Surprise)-lávabarlang részlete a Hawaii-szigetek fö szigetén, Hawaiin (fotó: Leél-Őssy Sz.)

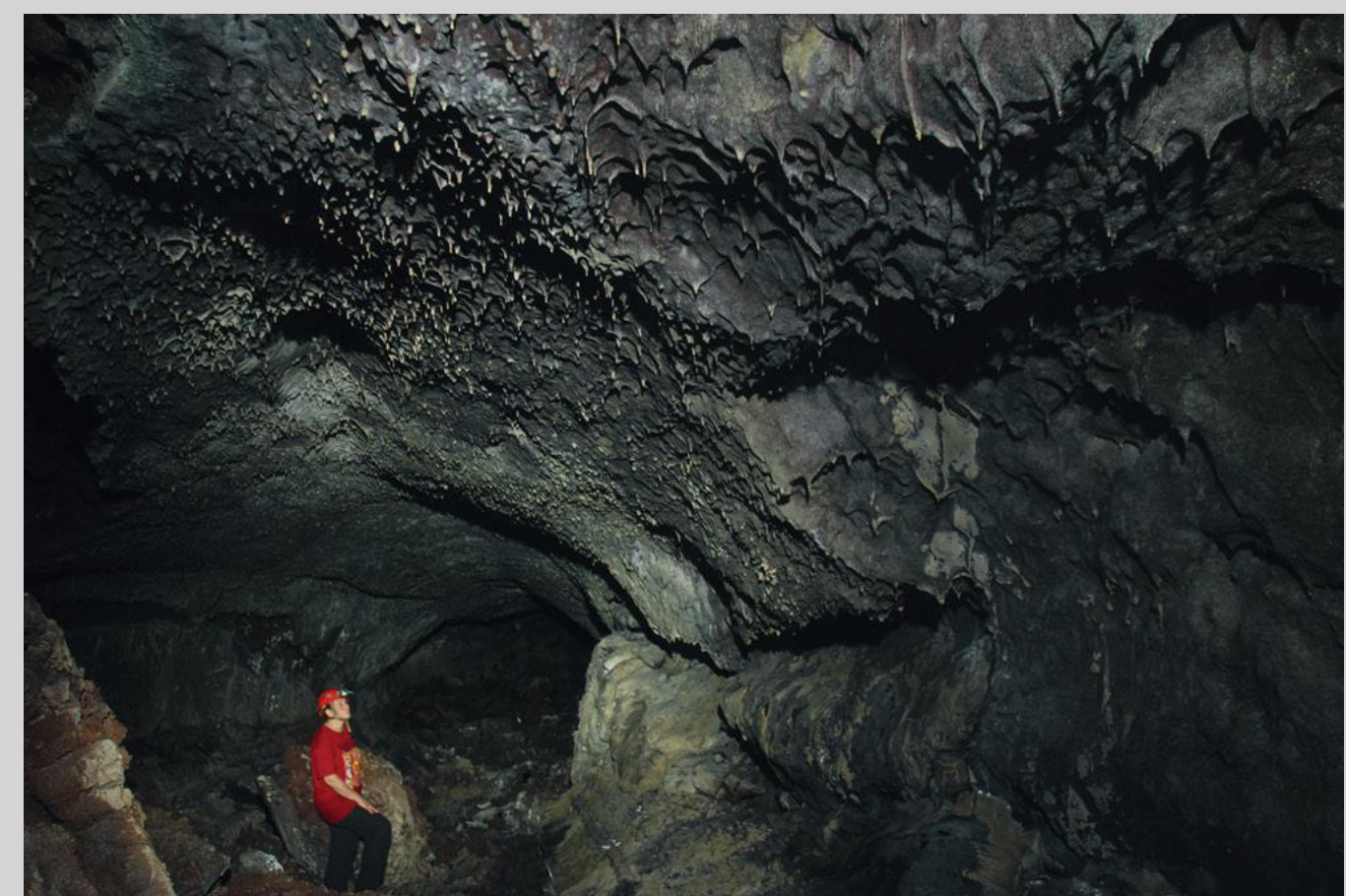


1996. évi LIII. törvény is, amely alapján Magyarországon minden barlang ex lege (azaz a törvény erejénél fogva) védett, amennyiben belső mérete lehetővé teszi egy ember számára a behatolást, és a hossza meghaladja a 2 métert. Ez a feltáratlan és a kitöltött barlangokra is vonatkozik! Mindez nemzetközi összehasonlításban is igen szigorú védelemnek számít. (Ennek értelmében nem szerencsés a mesterségesen kialakított föld alatti üregeket barlangnak nevezni.) A Magyarországon nyilván tartott barlangok közül 145 fokozottan, 260 megkülönböztetetten védett, és 5 gyógybarlangunk is van.

\section{A BARLANGOK LEGFÖBB DÍSZEI: A CSEPPKÖVEK}

Akármilyen eredetű is a barlang, a karbonátos kőzeteken átszivárgó vagy feltörő víz látványos, leggyakrabban kalcit vagy aragonit anyagú kiválásokat rak le bennük. Ezek közül a legközönségesebb és legismertebb képződmény a cseppkő. A cseppkövekről mindenki tudja, hogy igen lassan képződnek. Turistáknak vezetett barlangtúrákon a vezető többnyire mond valamilyen nehezen ellenőrizhető, hihetetlenül lassú képződési adatot. Az igazság az, hogy a cseppkőképződés is (akárcsak a legtöbb földtani folyamat) emberi léptékkel nézve valóban lassú, de földtörténeti léptékkel viszonylag gyors folyamat. Például az elmúlt évtizedek vizsgálataiból tudjuk, hogy a Baradlában van olyan kidőlt, 6 m hosszú, emberderéknál vastagabb cseppkőoszlop (6. ábra), amelyiknek a legidősebb rétege is „csak” 28000 éves! A legidősebb meghatározott korú cseppkő itt a szintén kidőlt Zeppelin az Óriások-termében, aminek a talpán 300000 éves réteget találtunk.

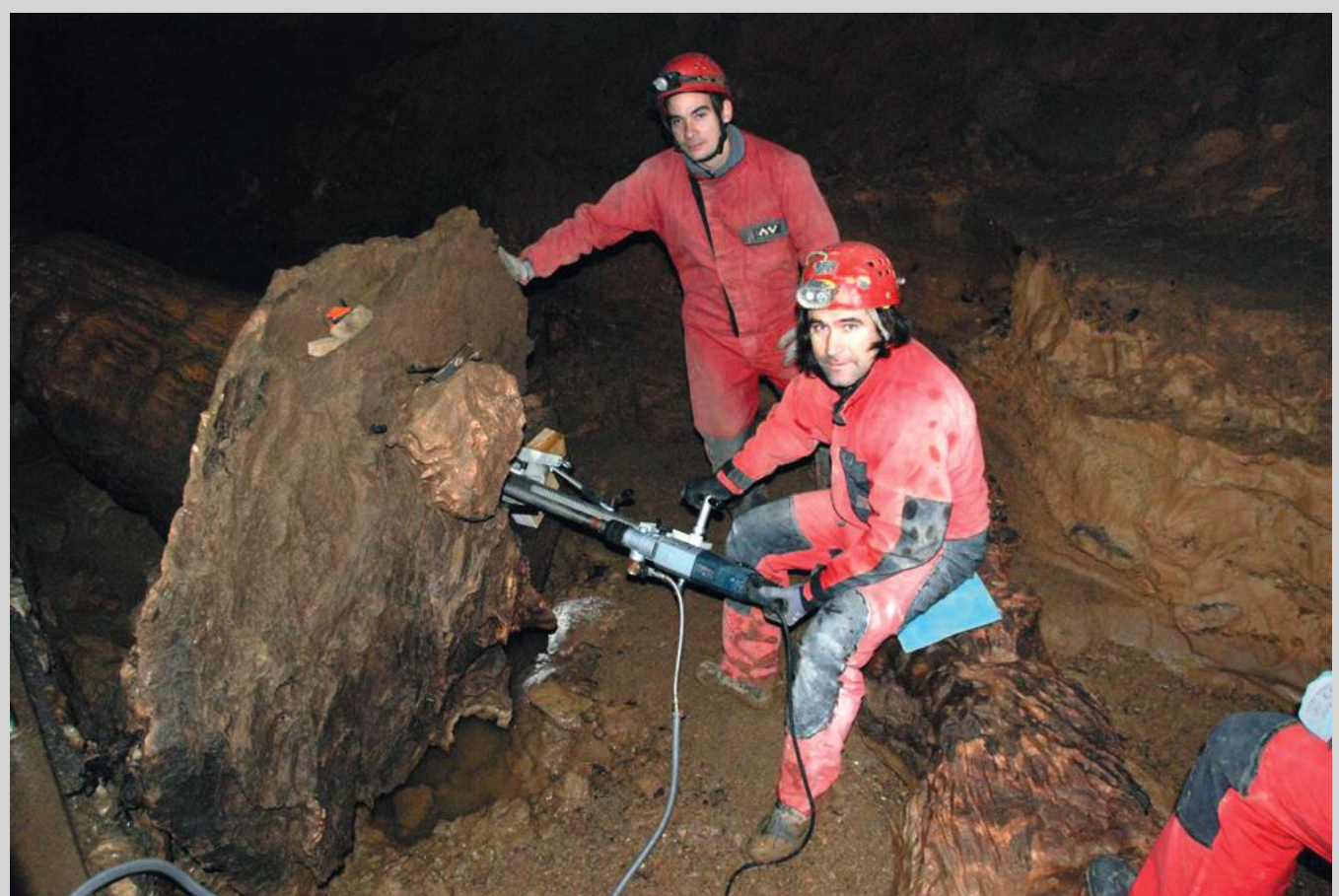


A Pál-völgyi-barlang Óriás-cseppköve pedig 350000 évesnél is idősebbnek bizonyult. Ugyanakkor mesterséges, beton anyagú létesítményeken már néhány év alatt is több centiméteres cseppkövek keletkezhetnek! Amikor több mint 40 éve a recski bánya mélyszintjén $1 \mathrm{~km}$-nél is mélyebben széles tárót hajtottak, az ott csepegő meleg vízből néhány év alatt látványos, nagyméretű cseppkőlefolyások váltak ki.

Hogyan tudjuk megállapítani a cseppkövek abszolút korát? A radiometrikus, azon belül az uránsoros kormeghatározás biztosít erre lehetőséget. A radiometrikus korhatározás minden fajtájához ismerni kell a természetben az adott elem stabil és radioaktív (tehát önmagától, spontán módon átalakuló) izotópjainak az arányát, a radioaktív izotóp felezési idejét (amennyi idő alatt a teljes izotópmennyiség fele elbomlik), és a mintában az eredeti radioaktív, valamint a belőle keletkezett (már elbomlott) ún. „leányizotópok” arányát. Ehhez ezen kívül szükséges még, hogy a rendszer (a vizsgált kőzet, illetve ásvány) a keletkezése óta zárt legyen (azaz nem távozhatott el belöle valamilyen leányizotóp, illetve nem kerülhetett bele további, kiindulási radioaktív izotóp).

Az uránsoros módszer azt az ismert folyamatot használja fel, hogy a ${ }^{238} \mathrm{U}$ izotópból több mint egy tucat lépés során végül ${ }^{206} \mathrm{~Pb}$ (ólom) izotóp lesz. A közben létrejövő leányizotópok egy része nagyon rövid, másik részük hosszú életü. Legpraktikusabb a hosszú felezési idejü tórium ${ }^{230} \mathrm{Th}$ izotópjának a mérése. A tórium ugyanis a karsztvízben nem oldódik, csak törmelékes elegyrészekhez kötődve mozog. Ugyanakkor az urán (bár csak kis mennyiségben) oldott állapotban jelen van a karsztvízben. Tehát ha tiszta karsztvízből kivált kalcit anyagú képződményt vizsgálunk (a cseppkő ilyen), akkor annak a keletkezésekor nem volt tóriumtartalma, az csak az urán bomlása során kerülhetett bele. Így a minta ${ }^{238} \mathrm{U}$ és ${ }^{230} \mathrm{Th}$ arányának megmérése után kiszámolható, hogy mikor kezdődött meg a bomlás, azaz mikor vált a cseppkő kiválásával zárttá a rendszer (LeÉL-Össy Sz. LAuritzen, S-E. 1994, SikLósy Z. et al. 2011).

Persze ennek is, mint minden radiometrikus korhatározásnak számos buktatója lehet. Például mégsem volt mindig zárt a rendszer, illetve agyagos, esetleg tóriumtartalmú frakció is belekerülhetett a képződménybe. A mintavétel (7. ábra) és a meghatározás, a mérés során is sok hibát lehet elkövetni - különösen, ha a képzödmény urántartalma alacsony (pl. fél g/t alatti). A mérési módszerek korszerűsödése, a vizsgálathoz szükséges minta mennyiségének csökkenése (különösen a tömegspektrometriás mérések alkalmazása óta) javítja a módszer pontosságát. Gondoljunk bele, hogy a fa évgyürüihez hasonló szerkezetű cseppkövek (8. ábra) egy-egy rétege sokszor csak 1-2 tized mm széles, így abból csak kis mennyiségü minta nyerhető ki! Ha mennyiségi igény miatt több rétegből vesszük a mintát, akkor csak egy átlagértéket fogunk kapni, nem egy-egy rétegnek a pontos korát. 


\section{A CSEPPKÖVEK TUDOMÁNYOS VIZSGÁLATÁNAK CÉLJAI ÉS EREDMÉNYEI}

A cseppkövek tehát árulkodnak a korukról, ha megfelelő módszerrel „vallatjuk” őket. Azonban más módszerekkel többet is elárulnak magukról, például a képződésükkor fennálló meteorológiai viszonyokról. Ez pedig napjaink kulcsfontosságú kérdése, a jelenleg legtöbbet kutatott témakör: az éghajlatváltozás. A fejlett világban tapasztalható, eltérő mértékű, de egyértelmüen kimutatható átlaghőmérséklet-emelkedés - amit a napi sajtóban "globális felmelegedésként”, „klímaváltozásként”, harsányabb megfogalmazásban „klímakatasztrófaként” emlegetnek - következményei, köztük a várható világméretü, azaz eusztatikus tengerszint-emelkedés, a szélsőségesebbé váló időjárás, a tenyészidőben meghosszabbodó és gyakoribbá váló aszályos időszakok, az elsivatagosodás, és az ezek következtében fellépő élelmiszer- és ivóvízhiány igen riasztók.

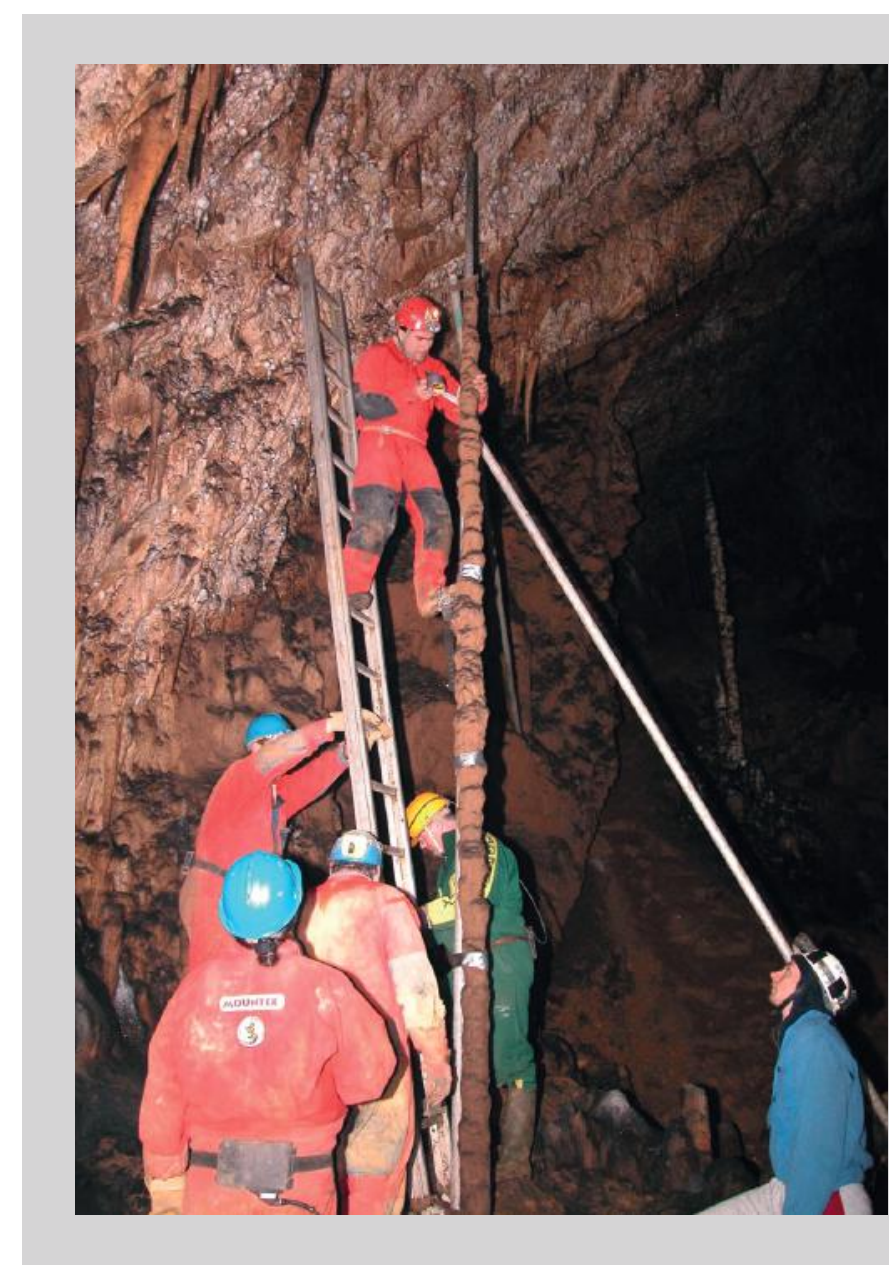

7. ábra. Cseppkö mintavétele a Baradla Olimposz nevü terménél (fotó: Leél-Össy Sz.)

A tengerszint jelentős emelkedése sok 
száz millió ember lakóhelyét öntené el pl. Dél- és Délkelet-Ázsiában. Tudjuk, hogy a sarkvidékeken és a magashegységekben ma található jégtakaró teljes elolvadása közel 70 méterrel emelné meg a világtenger szintjét. És a földtörténet nagy részében nem volt sarki jégsapka a bolygónkon...

Ma már általánosan elfogadott, hogy az emberiség által az ipari forradalom kezdete óta kitermelt, elsősorban a földtörténeti múltban keletkezett ún. fosszilis tüzelőanyagok (kőszén és kőolajtermékek) elégetése során a légkörbe került szén-dioxid (és más felszabaduló egyéb üvegházhatású gázok) melegítik az éghajlatot. Ugyanakkor a földtudósok már régen kimutatták, hogy a Föld éghajlata jelentős szélsőségek között ingadozott az elmúlt évmilliók, évszázmilliók folyamán, jóval az emberi tevékenység megindulása elött is, és az szélsőségesen befolyásolta az eljegesedett területek kiterjedését. Például a negyedidőszaki „jégkor” utolsó hideg periódusa, a würm glaciális óta, azaz az utolsó 10 000-12 000 évben a magasabb szélességi körökön elterülő jég elolvadása következtében a világtenger vízszintje napjainkig kb. 130 métert emelkedett! Hogy mennyi a napjainkban lezajló változásokból a természetes folyamatok következménye, és mennyi az emberi tevékenység hatása? Erre a nehéz kérdésre a tudományos igényü (és nem szenzációhajhász) válaszadást megkönnyíti, ha minél jobban megismerjük a régmúlt idők éghajlatváltozásait, amelyek még mentesek voltak az emberi behatástól. Az ilyen irányú kutatásokhoz nyújtanak segítséget a cseppkövek.

A cseppkövek ugyanis a barlangokban háborítatlan környezetben fejlődnek, sokszor több tízezer, vagy több százezer évig (l. fentebb). A felszínen lerakódott fiatal, laza kiválások ugyanakkor gyorsan átalakulnak, lepusztulnak, és néhány évezred távlatából már csak korlátozottan vizsgálhatók. Nekünk nincs tengerünk, amikben a fiatal üledékek szintén megőrződhetnek, betemetődhetnek, viszont van sok barlangunk, és sokban van cseppkő is. Ezek között vannak kitört példányok is, és a szigorú természetvédelmi szabályok betartásával minimális mennyiségű mintát élő cseppkövekből is nyerhetünk. A stabil izotópos elemzések (elsősorban a szén és az oxigén módosulatainak vizsgálata) alapján szerezhetünk adatokat az egyes rétegek keletkezési idejében fennállt éghajlatról. (Ezért fontos az egyes rétegek pontos korhatározása: a stabil izotópok által szolgáltatott adatok csak akkor használhatók számunkra, ha a vizsgált rétegek keletkezési korát is tudjuk.)

$\mathrm{Az}$ oxigénizotópok arányából, ezek egyes cseppkőrétegekben megfigyelhető változásából következtethetünk a cseppkövet tápláló beszivárgó víz, ezen keresztül a csapadékvíz összetételére és mennyiségére, így a hidrológiai cikluson keresztül az éghajlatra. A szénizotópok aránya, illetve annak rétegenkénti változása a barlang feletti növényzet alakulását, a talajaktivitást, illetve a kőzet-víz kölcsönhatást mutatja. A növényzeten kívül a teljes biológiai aktivitásra (beleértve a növényzet mellett a 
talajlakó szervezeteket is), és közvetve a csapadék mennyiségének változására is utal a cseppkőben található foszfor mennyisége. A csapadékviszonyokra, azaz a kőzet repedésein át a barlangba beszivárgó víz mennyiségére a barlangi kiválásokat „szennyező” stroncium is hordoz információt.

A fentiek vizsgálatára - a Csillagászati és Földtudományi Kutatóközpont irányításával - kutatócsoport alakult, amelynek e sorok írója is tagja. A cseppkövek korának megállapítását Surányi Gergely, a stabil izotópos vizsgálatokat Demény Attila, Czuppon György, Hatvani István, Kern Zoltán, Németh Alexandra és Siklósy Zoltán végezte, számos külföldi szakemberrel való együttmüködésben. Kutatásaink során azt tapasztaltuk, hogy az egyes cseppkövek növekedése korántsem volt egyenletes. Gyarapodásuk néha felgyorsult, néha lelassult, sőt a hidegebb periódusok idején évtízezredekre le is állt. Ezeket az adatokat különböző helyszíneken nyert információkkal, illetve egyéb módszerek alkalmazásával szerzett eredményekkel kell összevetni, hogy egységes képet alkothassunk egy-egy terület múltbeli éghajlatváltozásairól.

Cseppkövekkel kapcsolatos vizsgálataink a legutóbbi években más eredményre is vezettek: bizonyítottuk a baktériumok szerepét a növekedésükben (ENYEDI N. et al. 2020; Eötvös Loránd Kutatási Hálózat hírlevele 2020a). Ebben egy újabb kutatócsoport vett részt: a Baradlában a cseppkövek gyarapodó felszínéról Berentés Ágnessel gyüjtött mintáinkat Borsodi Andrea, Enyedi Nóra és Makk Judit biológusok vizsgálták, Németh Péter pedig elektronmikroszkópos felvételeket készített róluk (9. ábra). A vizsgálatokat azért kezdtük el, mert a stabil izotópos elemzések során bebizonyosodott, hogy a cseppkövek apró üregeiben megmaradt oldatokban megváltozik a csepegő víz jellemző ${ }^{18} \mathrm{O} /{ }^{16} \mathrm{O}$ aránya, és az ${ }^{16} \mathrm{O}$ jelentős mértékben feldúsul bennük. Ezt az amorf kalcium-karbonát okozza, amelynek kristályos szerkezetűvé való átrendeződése, kalcittá válása felszíni körülmények között percek alatt bekövetkezik, de a barlangban a cseppkövek felületén hetekig-hónapokig stabil marad. Ezért a gyüjtött mintákat hűtőtáskában szállítottuk a barlangból vizsgálatra. A mikrobiológiai vizsgálatok szerint a baktériumok alkotta szerves burok zsírsavai stabilizálják az amorf kalcium-karbonátot.

Azt, hogy a baktériumoknak milyen hatása van a cseppkőképződés sebességére, úgy tanulmányoztuk, hogy a Baradla turisták által kevéssé látogatott részén, a Nehézútnak nevezett barlangszakaszban UV-fényt is kibocsátó germicidlámpával világítottunk meg egy cseppkőkiválási pontot (Eötvös Loránd Kutatási Hálózat hírlevele 2020b). A közelben egy másik kontrollpont sötétben maradt. Mindkét ponton a csepegő víz alá üveglemezt helyeztünk. A germicidlámpa elhelyezését az Aggteleki Nemzeti Park szakembereinek hathatós segítségével három hónaponként felcseréltük a két helyszín között. Begyüjtöttük az üveglapon kivált karbonátmintákat, és azt tapasztaltuk, hogy 


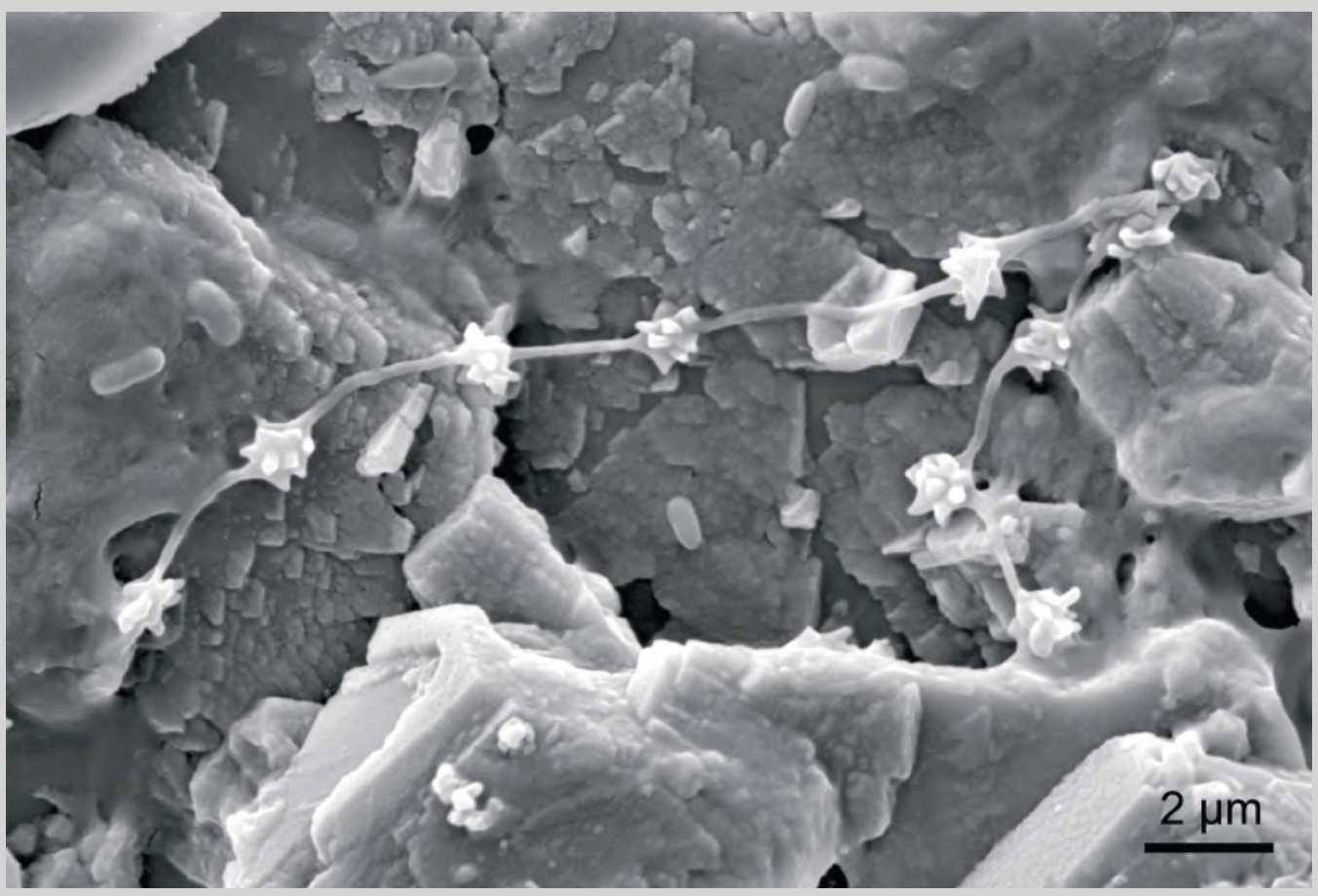

9. ábra. Baradlai szalmacseppkövön megtelepült baktériumok pásztázó elektronmikroszkópos képe (fotó: Makk J.)

a mikromorfológiai-mikromineralógiai jellemzőik jelentősen eltértek egymástól. Az UV-lámpával megvilágított felszínen saját alakú kalcit kristálykák csapódtak ki a csepegő vízből, míg a természetes körülmények között, a barlangi sötétben történő kiválás során rendezetlen, biofilmmel burkolt megjelenésủ karbonátkiválást tapasztaltunk.

A cseppkövek vizsgálatai további érdekességgel is szolgálhatnak. A „kapcsolt izotópok geokémiája" új tudományterületéhez kapcsolódva a debreceni Atommagkutató Intézetben sikerült létrehozni egy laboratóriumot, amely alkalmas kapcsolt izotópok mérésére (DEMÉNY A. et al. 2021). Vizsgálatainkat ebben az irányban kívánjuk folytatni. Ettől a kutatástól azt várjuk, hogy a karbonátkiválások keletkezésének hőmérsékletére kapjunk információt. Az egyes barlangok hőmérséklete ugyanis egész évben állandó, általában a bejárat közelében tapasztalható éves átlaghőmérsékletnek feleltethető meg. Így azt is megtudhatjuk, hogy az egyes cseppkőrétegek keletkezésekor milyen volt a terület átlaghőmérséklete. 


\section{ÖSSZEGZÉS}

A hazánkban ismert valamennyi jelentősebb barlang természet- és életvédelmi okokból zárt terület és csak képesített vezetővel látogatható. Igaz ez mind a turisták számára megnyitott, utcai ruhában is látogatható, villanyvilágítással ellátott tucatnyi idegenforgalmi barlangra a Mecsekben, a Balaton-felvidéken, Budapest környékén, a Bükkben és Aggtelek körzetében, mind pedig a kiépítetlen hosszabb, labirintusos vagy jelentős függöleges kiterjedéssel bíró barlangra. Ezek közül többe vezetnek amatörök számára is overallos „kalandtúrákat” a Balaton-felvidéken, Budapesten vagy az Aggteleki-karsztvidéken is. A többi barlangba csak képesített barlangjárók mehetnek be vizsgázott barlangi túravezető helyszíni irányítása mellett. A legféltettebbekbe, a legsérülékenyebbekbe (pl. a Beremendikristálybarlangba, vagy a József-hegyi-barlangba) pedig kizárólag kutatási céllal adnak ki belépési engedélyt a területileg illetékes nemzeti parkok, pusztán csak látogatásra nem.

Azonban a barlangokban nemcsak a természet remekművét kell megcsodálni, hanem érdemes tudományos módszerekkel megpróbálni megfejteni azokat a kódolt információkat, amelyeket kinyerhetünk képződményeikböl. A cseppkövek anyagvizsgálatának, ennek az újszerű tudományterületnek még számos lehetősége fog megnyílni a jövőben. Elemzéseinktől további új adatokat várunk hazánk földtörténetileg közelmúltbeli éghajlatváltozásairól.

\section{IRODALOM}

Demény A. - Rinyu L. - Németh A. - Czuppon Gy. - Enyedi N. - Makk J. - LeéL-Össy Sz. - Kesjár D. - Kovács I. (2021): Bacterial and abiogenic carbonates formed in caves - no vital effect on clumped isotope compositions. - PLoS One 16. 1. e0245621. https://doi.org/10.1371/journal.pone.0245621

Enyedi N. - Makk J. - Kótai L. - Berényi B. - Klébert S. - Sebestyén Z. - Molnár Z. - Borsodi A. K. - LeÉL-Össy S. - Demény A. - NÉmeth P. (2020): Cave bacteria-induced amorphous calcium carbonate formation. - Scientific Reports 10. 8696. https://doi.org/10.1038/s41598-020-65667-w

ERőss A. - MÁdL-SzŐNyi J .- Csoma A. É. (2010): The effects of mixed hydrothermal and meteoric fluids on karst reservoir development, Buda Thermal Karst, Hungary. - EMR Final Report, SIEP Rijswijk. $120 \mathrm{p}$.

Ford, D. - Williams, P. (2007): Karst hydrogeology and geomorphology. - John Wiley \& Sons, Chichester. 562 p. https://doi.org/10.1002/9781118684986

GunN, J. (szerk. 2004): Encyclopedia of caves and karst. - Taylor and Francis Group, New York-London. 1940 p. https://doi.org/10.4324/9780203483855

JAKUCS L. (1971): A karsztok morfogenetikája. A karsztfejlődés varienciái. - Akadémiai Kiadó, Budapest. 311 p.

JAKUCS L. (2005): Néhány szó a patakbarlangokról. - Karszt és Barlang 2000-2001. pp. 3-15.

LeÉL-Össy Sz. - LAuritzen, S-E. (1994): Egyes baradlai cseppkövek radiometrikus kora. - Karszt és Barlang 1994. pp. 12-15. https://doi.org/10.23928/foldt.kozl.2018.148.1.45 
LeÉL-Őssy Sz. - Virág M. (2018): Az utóbbi 20 év barlangkutatási eredményei a Budai-hegységben (különös tekintettel a Rózsadomb környékére). - Földtani Közlöny 148. 1. pp. 45-74.

Siklósy Z. - Demény A. - LeéL-Össy Sz. - Szenthe I. - Lauritzen, S-E. - Shen, C. C. (2011): A cseppkövek kormeghatározása és azok paleoklimatológiai jelentősége. - Földtani Közlöny 141. 1. pp. 73-87.

Veress M. (2004): A karszt. - Berzsenyi Dániel Főiskola Természetföldrajzi Tanszék, Szombathely. 215 p.

Eötvös Loránd Kutatási Hálózat hírlevele (2020a): https://ttk.elte.hu/content/a-baradla-barlangbakteriumai-segitik-a-klimakutatast.t.3400.

Eötvös Loránd Kutatási Hálózat hírlevele (2020b): https://elkh.org/hirek/bakteriumok-mindenhol-a-cseppkokepzodes-mechanizmusanak-ujszeru-vizsgalata-a-foldtudomany-a-mikrobiologia-es-a-fizika-kutatoinak-osszefogasaval 